\title{
Adsorption of reactive blue BF-5G dye on MCM-41 synthesized from Chocolate clay
}

\section{(Adsorção do corante reativo azul BF-5G por MCM-41 sintetizada a partir da argila Chocolate)}

\author{
L. N. R. de Paula ${ }^{1}$ G. M. de Paula ${ }^{1}$, M. G. F. Rodrigues ${ }^{1 *}$ \\ ${ }^{1}$ Federal University of Campina Grande, Department of Chemical Engineering, \\ Av. Aprígio Veloso 882, 58429-970, Campina Grande, PB, Brazil
}

\begin{abstract}
The efficiency of as-synthesized and calcined mesoporous silica, using clay as a silica source, to remove the reactive blue BF-5G dye was investigated. The materials were characterized by X-ray diffraction (XRD) analysis, energy-dispersive X-ray fluorescence (ED-XRF), and Fourier-transform infrared spectroscopy. The kinetic and adsorption isotherms were also studied. The XRD and EDXRF results showed that the Chocolate clay is rich in $\mathrm{SiO}_{2}(69.4 \%)$ and has a large amount of other oxides, which can be eliminated by acid leaching. According to the characterization results, the MCM-41 synthesis was effective and produced a highly-ordered material. The kinetic study showed the adsorption corresponded predominantly to the pseudo-second order model. Adsorption equilibrium was reached after $3 \mathrm{~h}$, and the data were better fitted to the Freundlich model. Furthermore, both samples obtained satisfactory removal results, being potential adsorbents having reduced cost due to the use of an alternative silica source.
\end{abstract}

Keywords: dye removal, MCM-41, adsorption, Chocolate clay, reactive blue BF-5G.

Resumo

A eficiência da sílica mesoporosa sintetizada e calcinada, utilizando argila como fonte de sílica, foi investigada quanto à sua capacidade de adsorver o corante reativo azul BF-5G. Os materiais foram caracterizados por difração de raios X (DRX), fluorescência de raios $X$ por dispersão de energia (FRX-ED) e espectroscopia na região do infravermelho. A cinética e as isotermas de adsorção também foram estudadas. Os resultados de DRX e FRX-ED mostraram que a argila Chocolate é rica em $\mathrm{SiO}_{2}$ (69,4\%) e possui uma grande quantidade de outros óxidos, que podem ser eliminados pela lixiviação ácida. De acordo com os resultados de caracterização, a síntese do MCM-41 foi eficaz e produziu um material altamente ordenado. O estudo cinético mostrou que a adsorção correspondeu predominantemente ao modelo de pseudossegunda ordem. O equilíbrio da adsorção foi atingido após $3 \mathrm{~h}$ e os dados foram melhor adaptados ao modelo de Freundlich. Além disso, ambas as amostras obtiveram resultados satisfatórios de adsorção, sendo potenciais adsorventes com custo reduzido devido ao uso de uma fonte alternativa de sílica (argila Chocolate). Palavras-chave: $M C M-41$, adsorção, argila Chocolate, corante reativo azul BF-5G.

\section{INTRODUCTION}

The amount of textile dyes discharged globally as industrial effluents is estimated to be around 280000 tons per year [1]. Approximately $50 \%$ of the total amount of dye used does not become fixed to the fibers, remaining present in wastewater [2]. The release of dye effluents into the environment has generated a threat to human health and the ecosystem, since they have been identified as toxic, mutagenic, and also carcinogenic [3]. Disposal of dyes into aquatic bodies, especially azo chemical dyes, also creates a serious hazard to aquatic life, because biodegradation may lead to the formation of dangerous aromatic amines [4]. The resistance of dyes to degradation makes their removal from textile wastewaters complicated because it is difficult

*meiry.rodrigues@ufcg.edu.br

Dhttps://orcid.org/0000-0003-2258-4230 to degrade the mixture of dyes and additional chemicals through conventional treatment processes [5]. Traditional technologies for the treatment of textile wastewater include various combinations of biological, physical, and chemical methods. These methods, however, require high capital and operating costs [6]. Adsorption can be considered an effective alternative to traditional methods. In general, the adsorbent's ability to remove the dye and other chemicals depends mainly on its contact area and the active exchange sites [7]. It is, therefore, necessary that these adsorbents have many active exchange sites as well as a large contact area. Some of the most efficient methods are technologies based on the adsorption of effluents using a range of adsorbents, among which can be highlighted activated carbon $[8,9]$, polymeric ionic liquid [10], silica aerogel [11], activated alumina [12], zeolites [13], bentonites [14], and molecular sieves [15].

More specifically, MCM-41 molecular sieve is an 
amorphous silicate that has a hexagonal arrangement of uniform mesopores with a high surface area that reach up to $1200 \mathrm{~m}^{2} / \mathrm{g}$, when the material is calcined [16]. The characteristics of this material allow it to be used for several chemical processes, especially in catalytic processes [1720]. Recent studies have reported positive effects of the assynthesized MCM-41 on catalytic processes and adsorption processes [21-24]. The existence of a cationic surfactant within the pores of the MCM-41 generates basic sites that cause modifications to the chemical contact area and the porosity of the material, positively affecting the behavior of the molecular sieve as catalyst and adsorbent [22, 23]. MCM-41 with an HDTMA (hexadecyltrimethylammonium) as a surfactant was used as an adsorbent in aqueous solutions to remove toluene and cumene, and the results proved that adsorption was governed by both porosity and cationic spots generated by cationic templates [25]. Using Al-MCM-41 as adsorbent of yellow dye molecules from aqueous solution, Boukoussa et al. [23] reached the highest adsorption capacities for uncalcined materials. However, the high production cost of MCM-41 limits its applications to a large scale, and this has motivated efforts to develop effective syntheses using natural reagents [19]. In the search for alternative materials with lower costs, this study seeks to examine the potential of MCM-41, using Chocolate clay as a silica source, as an adsorbent for the removal of reactive blue BF-5G dye from an aqueous solution. The Chocolate clay is essentially composed of microcrystalline particles of a small group of minerals, referred to as the clay minerals [26]. Compared with TEOS (tetraethyl orthosilicate), clay materials are a natural source of silica, being inexpensive and present high reactivity [1].

\section{MATERIALS AND METHODS}

Materials: Chocolate clay was supplied by Bentonisa Bentonite Nordeste, João Pessoa, Brazil. All the chemical reagents used in this study were of analytical grade and used without further purification. Vetec provided cetyltrimethylammonium (CTAB, 98\%), sulfuric acid $\left(\mathrm{H}_{2} \mathrm{SO}_{4}, 95-98 \%\right)$, and sodium hydroxide $(\mathrm{NaOH}, 97 \%)$. Tetraethyl orthosilicate (TEOS), tetramethylammonium hydroxide pentahydrate (TMAOH, 97\%), and hydrochloric acid $(\mathrm{HCl}, 37 \%)$ were purchased from Sigma-Aldrich. Reactive blue BF-5G was supplied by Texpal Quím., São Paulo, Brazil. BF-5G is a bifunctional dye from the azo chemical class and commonly used in the dyeing of cellulose fibers. The chemical structure of BF-5G is shown in Fig. 1.

Modification of Chocolate clay: firstly, Chocolate clay was crushed and sieved through a 200 mesh screen to obtain particles smaller than $0.074 \mathrm{~mm}$. Then, it was treated with a $6 \mathrm{~mol} . \mathrm{L}^{-1}$ sulfuric acid solution at a ratio of 1:6 (w/v) at 100 ${ }^{\circ} \mathrm{C}$ for $2 \mathrm{~h}$ to remove excess iron and aluminum from the octahedral layer. Afterward, the solid material was filtered, washed, and oven-dried at $100{ }^{\circ} \mathrm{C}$ for $24 \mathrm{~h}$. The Chocolate clay was then treated with a $1 \mathrm{~mol} . \mathrm{L}^{-1}$ sodium hydroxide solution at a ratio of $1: 7(\mathrm{w} / \mathrm{v})$ for $6 \mathrm{~h}$ at $100^{\circ} \mathrm{C}$ under stirring.

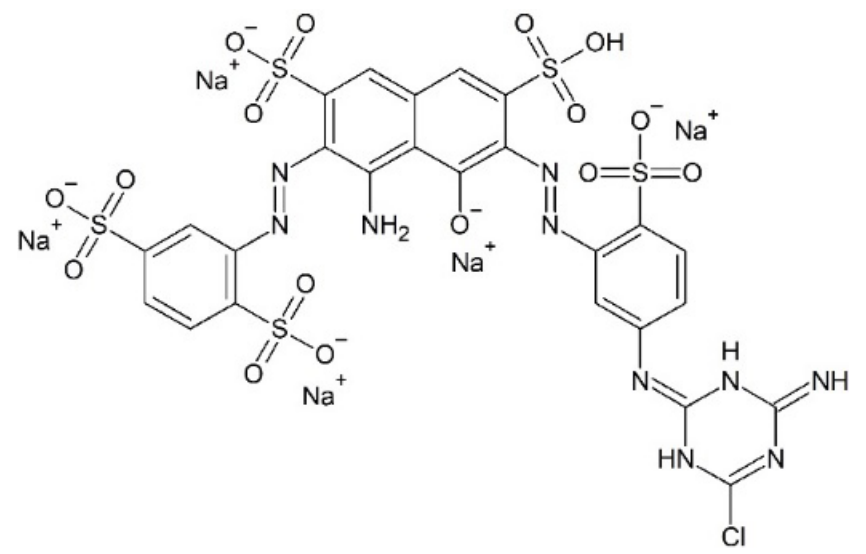

Figure 1: Molecular structure of BF-5G (CAS 147826-71-9; molecular weight 1021.14 g.mol ${ }^{-1} ; \mathrm{C}_{25} \mathrm{H}_{14} \mathrm{ClN}_{10} \mathrm{Na}_{4} \mathrm{O}_{16} \mathrm{~S}_{5}$ ).

[Figura 1: Estrutura molecular do BF-5G (CAS 147826-71-9; massa molecular 1021,14 g.mol $\left.{ }^{-1} \mathrm{C}_{25} \mathrm{H}_{14} \mathrm{ClN}_{10} \mathrm{Na}_{4} \mathrm{O}_{16} \mathrm{~S}_{5}\right)$.]

The mixture was cooled and filtered, and the filtrate became an alternative silica source for the synthesis of MCM-41.

Synthesis of MCM-41 molecular sieve: MCM-41, using Chocolate clay as a silica source, was synthesized by the hydrothermal method based on changes made to the classic procedure reported in the literature [27]. As a first step, $4.723 \mathrm{~g}$ of cetyltrimethylammonium bromide (CTAB) were dissolved in $30 \mathrm{~g}$ of distilled water, under stirring, at $50{ }^{\circ} \mathrm{C}$ for $2 \mathrm{~h}$. Then, the solution was cooled to $28^{\circ} \mathrm{C}$, and the silica source, previously dissolved in a sodium hydroxide solution, was added. The $\mathrm{pH}$ of the reaction mixture was controlled to reach $\mathrm{pH} 10$. After the $\mathrm{pH}$ was stabilized, the mixture remained under stirring at $28{ }^{\circ} \mathrm{C}$ for $2 \mathrm{~h}$. The material was then submitted to hydrothermal treatment at $150{ }^{\circ} \mathrm{C}$ for 96 $\mathrm{h}$ in a Teflon crucible wrapped in a stainless-steel autoclave. Finally, the solid product was collected through filtration, washed with distilled water, and dried at $60^{\circ} \mathrm{C}$ for $24 \mathrm{~h}$. The muffle calcination technique was used to remove the $\mathrm{CTAB}$ from the pores of the MCM-41 molecular sieve. The material was calcined at $550{ }^{\circ} \mathrm{C}$ for $7 \mathrm{~h}$ using a $2^{\circ} \mathrm{C} . \mathrm{min}^{-1}$ heating rate. The as-synthesized sample was named Adsorbent 1 , and the

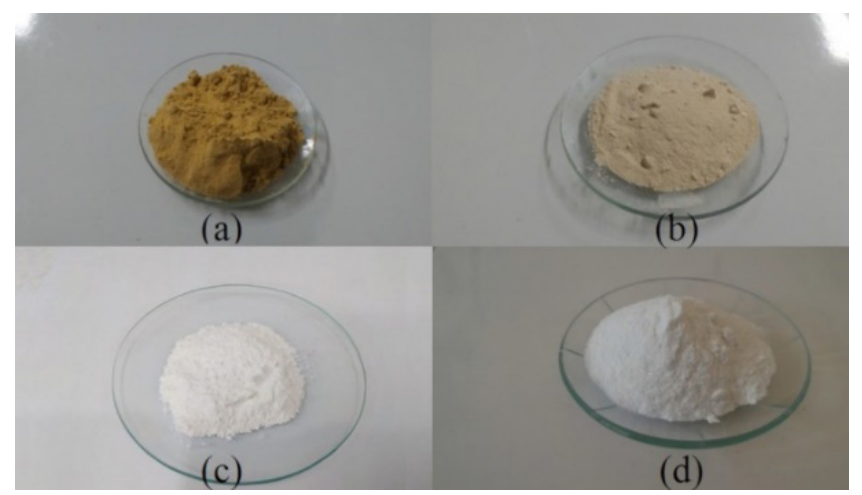

Figure 2: Images of samples: a) Chocolate clay; b) modified Chocolate clay; c) CTAB-MCM-41 (Adsorbent 1); and d) MCM41 (Adsorbent 2).

[Figura 2: Imagens das amostras: a) argila Chocolate; b) argila Chocolate modificada; c) CTAB-MCM-41; e d) MCM-41.] 
calcined sample was named Adsorbent 2. Fig. 2 shows the color of clays before and after leaching and the MCM-41 molecular sieves before and after calcination.

Characterizations of samples: X-ray diffraction (XRD) patterns were obtained with a diffractometer (Shimadzu, XRD 6000) using $\mathrm{CuK} \alpha$ radiation at $40 \mathrm{kV} / 30 \mathrm{~mA}$, with goniometer velocity of $2^{\circ} \cdot \mathrm{min}^{-1}$ and step of $0.02^{\circ}$ in the $2 \theta$ range from $2.0^{\circ}$ to $50.0^{\circ}$ and $1.0^{\circ}$ to $10.0^{\circ}$ for Chocolate clay and MCM-41, respectively. The elemental analysis of the samples was performed using energy-dispersive X-ray fluorescence (ED-XRF) spectrophotometer (Shimadzu, EDX-700). Fourier-transform infrared (FTIR) spectra of the samples were obtained using a spectrometer (Perkin Elmer, Spectrum 400). The samples were prepared by mixing 0.007 $\mathrm{g}$ of the sample and $0.1 \mathrm{~g}$ of $\mathrm{KBr}$, grinding and pressing the solid mixture at 5 ton during $30 \mathrm{~s}$ in order to form a pastille that allowed the transmission of light. The FTIR spectra were obtained in the range of 500 to $4000 \mathrm{~cm}^{-1}$ at $2 \mathrm{~cm}^{-1}$ resolution.

Batch adsorption experiments: BF-5G adsorption kinetics and isotherms were acquired in batch experiments. These experiments were performed at room temperature using a stock solution of $1000 \mathrm{mg} \cdot \mathrm{L}^{-1}$ of BF-5G dye, diluted to a concentration of $50 \mathrm{mg} . \mathrm{L}^{-1}$, which was put in contact with $0.1 \mathrm{~g}$ of adsorbent. The samples after adsorption were named Adsorbent 1 (Used) and Adsorbent 2 (Used). Adsorption experiments were conducted in conical flasks at controlled $\mathrm{pH}$ and under mechanical stirring at $200 \mathrm{rpm}$ (Tecnal, TE420). For the isotherm study, conical flasks containing 50 $\mathrm{mL}$ of dye solution with concentrations varying between 10 and $200 \mathrm{mg} . \mathrm{L}^{-1}$ were put in contact with adsorbent until reaching adsorption equilibrium $(3 \mathrm{~h})$. For the kinetic study, aliquots from the solution were collected at different time intervals between 1 and 180 min, taking care that the withdrawn volume did not exceed $8 \%$ of the total volume. Afterward, the solutions were filtered and analyzed for residual dye concentration with a UV-vis spectrophotometer (Shimadzu, UV-1800). The adsorbed quantity of dye was calculated using the following equation:

$$
\mathrm{q}_{\mathrm{eq}}=\frac{\left(\mathrm{C}_{0}-\mathrm{C}_{\mathrm{eq}}\right) \cdot \mathrm{V}}{\mathrm{m}}
$$

where $\mathrm{q}_{\mathrm{eq}}\left(\mathrm{mg} \cdot \mathrm{g}^{-1}\right)$ is the removal capacity at equilibrium, $\mathrm{C}_{0}$ and $\mathrm{C}_{\mathrm{eq}}\left(\mathrm{mg} \cdot \mathrm{L}^{-1}\right)$ are the initial and final concentrations of the dye, respectively, $\mathrm{V}(\mathrm{mL})$ is the volume of the adsorbate, and $\mathrm{m}(\mathrm{g})$ is the mass of adsorbent.

\section{RESULTS AND DISCUSSION}

Chocolate clay: Fig. 3 presents the X-ray diffractograms of natural and modified Chocolate clay. The natural Chocolate clay presented a characteristic peak corresponding to the clay mineral montmorillonite around $5.7^{\circ}$ and peaks that corresponded to the presence of kaolinite and quartz [28]. With respect to the modified Chocolate clay, there was a significant change in its structure. The characteristic peaks of montmorillonite and kaolinite disappeared. The sample also presented a halo between $15^{\circ}$ and $35^{\circ}$ relative to silica on the amorphous state, and peaks relative to crystalline silica, similar to the quartz pattern. These findings suggested that there was a possible distortion in the arrangement of the constituent ions of the octahedral and tetrahedral layers due to a probable ionic exchange, because the interlamellar arrangement is directly dependent on the cation [26, 29]. The leaching process was effective on the ionic exchange, a fact proved from the XRD patterns and elemental analysis (ED-XRF).

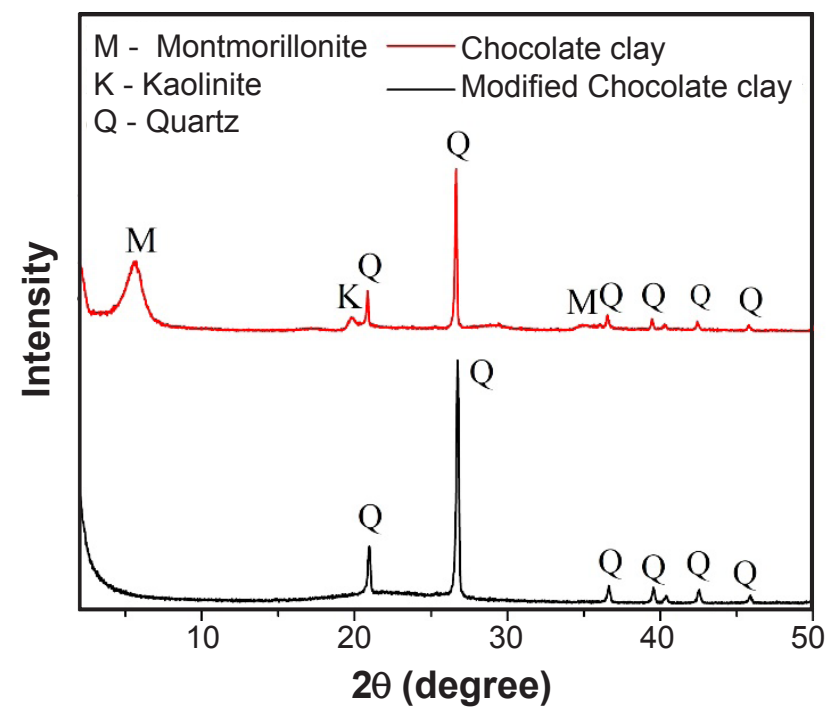

Figure 3: XRD patterns of natural and modified Chocolate clays. [Figura 3: Padrões de DRX das argilas Chocolate natural e modificada.]

Table I presents the chemical composition of the natural and modified Chocolate clay samples. The natural Chocolate clay showed a chemical composition with $\mathrm{SiO}_{2}$ and $\mathrm{Al}_{2} \mathrm{O}_{3}$ as major oxides. Considerable amounts of other oxides have also been identified, which were derived from the presence of quartz, kaolinite, and montmorillonite clay. High content of $\mathrm{Fe}_{2} \mathrm{O}_{3}(9.1 \%)$ was verified in the natural clay, where $\mathrm{Fe}^{3+}$ isomorphically substitutes $\mathrm{Al}^{3+}$ in the tetrahedral sheet. This behavior is typical of the smectite structure [4, 30, 31]. Regarding the chemical composition of the modified Chocolate clay (Table I), the applied acid treatment induced a reduction of the oxides $\mathrm{Fe}_{2} \mathrm{O}_{3}, \mathrm{Al}_{2} \mathrm{O}_{3}$,

Table I - Chemical composition (wt \%) of the Chocolate clay samples.

[Tabela I - Composição química (\% em massa) das amostras de argila Chocolate.]

\begin{tabular}{ccccccc}
\hline Sample & $\mathrm{SiO}_{2}$ & $\mathrm{Al}_{2} \mathrm{O}_{3}$ & $\mathrm{Fe}_{2} \mathrm{O}_{3}$ & $\mathrm{CaO}$ & $\mathrm{MgO}$ & Others \\
\hline $\begin{array}{c}\text { Natural } \\
\text { Chocolate } \\
\text { clay }\end{array}$ & 69.4 & 14.9 & 9.1 & 2.0 & 1.7 & 2.9 \\
$\begin{array}{c}\text { Modified } \\
\text { Chocolate } \\
\text { clay }\end{array}$ & 95.7 & 1.4 & 1.0 & - & - & 2.8 \\
\hline
\end{tabular}


$\mathrm{CaO}$, and $\mathrm{MgO}$, confirming that leaching of the octahedral cations $\mathrm{Fe}, \mathrm{Mg}$, and $\mathrm{Ca}$ took place. These findings suggested that the possibility of the modified Chocolate clay acting as Si source is very high; on the other hand, in the case of the source of $\mathrm{Al}$, this possibility is very remote.

$M C M-41$ : Fig. 4 presents the $\mathrm{X}$-ray diffractograms of the samples. The diffraction pattern of the as-synthesized sample, Adsorbent 1, presented a typical MCM-41 profile, indicated by peaks corresponding to the diffraction planes (100), (110), (200), and (210), associated with p6mm hexagonal symmetry. As reported [27, 32-35], the diffractogram of the MCM-41 molecular sieve must present these peaks, and these findings suggested the formation of the MCM-41 molecular sieve structure. Moreover, the calcined sample, Adsorbent 2, presented two distinct peaks unrelated to the MCM-41 hexagonal structure. The pore organization of the sample was lost, and it became a disordered mesoporous material. With respect to the samples after adsorption, some changes in the organization structure were noted. Adsorbent $1 \mathrm{had}$ a total loss of organization, with a total collapse of the structure. On the other hand, Adsorbent 2 maintained some level of organization in its structure. The aqueous solution can also influence the loss of structural organization of the adsorbents after use due to $\mathrm{H}_{2} \mathrm{O}$ physisorption in addition to the hydrolysis of the $\equiv \mathrm{Si}-\mathrm{O}-\mathrm{Si} \equiv$ bonds causing damage to the pore walls of the material and, therefore, reducing its structural stability [36].

Table II presents the chemical composition of the mesoporous samples, which presented high levels of silica, given that the structure of the molecular sieve consisted solely of silica.Although the technique fails to detect organic matter, it was observed that the as-synthesized sample contained an appreciable level of bromine, indicating the presence of the surfactant shaping the mesoporous structure. These results were in agreement with the literature [20]. Interestingly, no $\mathrm{Al}_{2} \mathrm{O}_{3}$ was observed in the chemical composition of the samples, and this finding confirmed the hypothesis that the modified clay acted only as a silica source.

Fig. 5 shows the FTIR spectra for the mesoporous samples. The samples presented bands characteristic of the symmetric and asymmetric stretching vibrations of the $\mathrm{Si}-\mathrm{O}-\mathrm{Si}$ groups, at the wavenumbers around 797, 1065-1098, and $1230 \mathrm{~cm}^{-1}$.
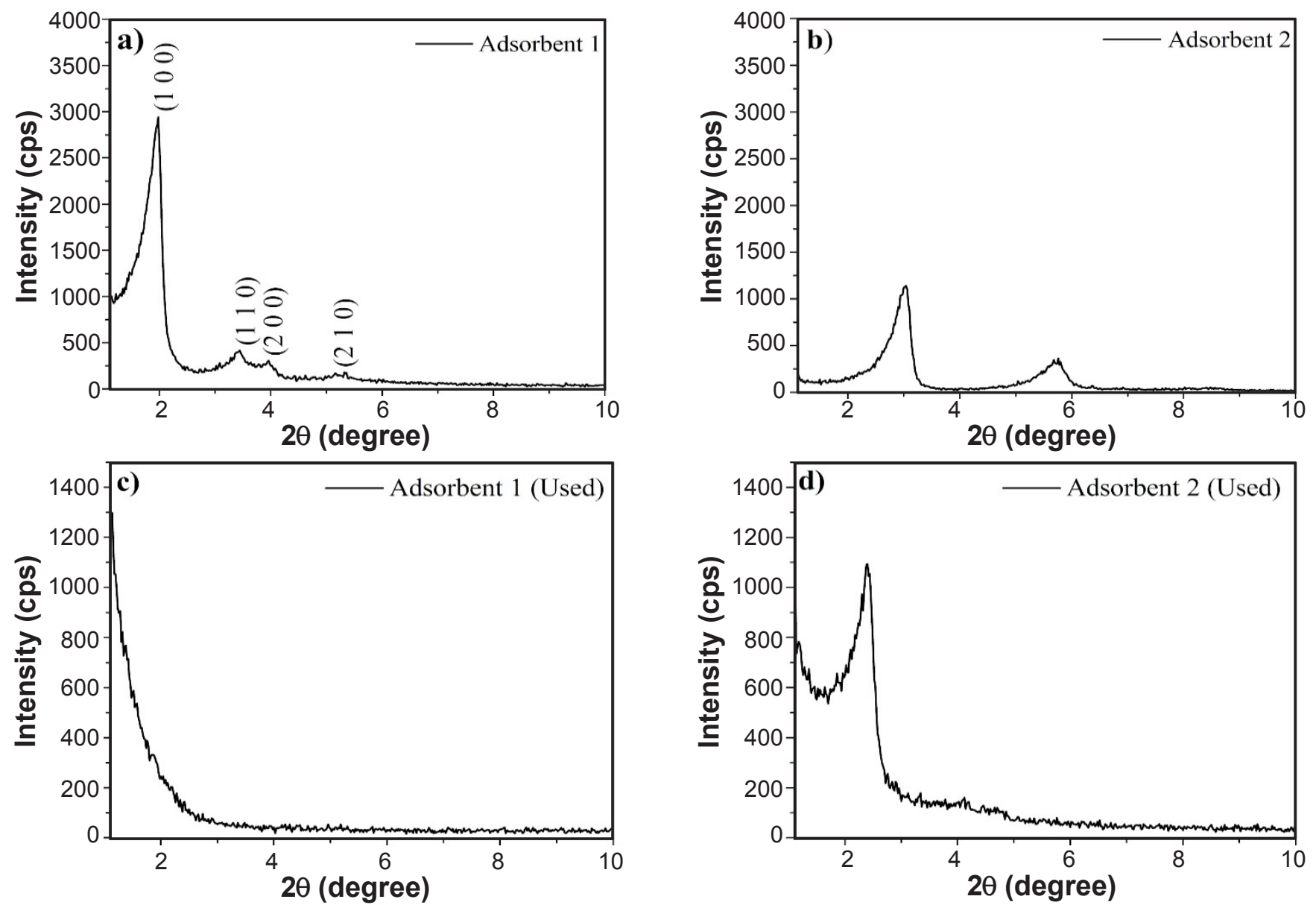

Figure 4: X-ray diffraction patterns of the mesoporous materials: a) Adsorbent 1; b) Adsorbent 2; c) Adsorbent 1 (Used); and d) Adsorbent 2 (Used).

[Figura 4: Padrões de difração de raios X dos materiais mesoporosos: a) Adsorvente 1; b) Adsorvente 2; c) Adsorvente 1 (Usado); e d) Adsorvente 2 (Usado).] 
Table II - Chemical composition (wt\%) of the mesoporous samples.

[Tabela II - Composição química (\% em massa) das amostras mesoporosas.]

\begin{tabular}{ccccc}
\hline Sample & $\mathrm{SiO}_{2}$ & $\mathrm{SiO}_{3}$ & $\mathrm{Br}$ & Others \\
\hline Adsorbent 1 & 97.6 & 1.5 & 0.2 & 0.7 \\
Adsorbent 2 & 98.6 & 1.0 & - & 0.4 \\
\hline
\end{tabular}

The samples also presented a band characteristic of the Si-OH groups at around $965 \mathrm{~cm}^{-1}$, and bands characteristic of the vibration and stretching of the $\mathrm{OH}$ bond, at around 1662 and $3440 \mathrm{~cm}^{-1}$, due to the presence of adsorbed water in the samples. The sample Adsorbent 1, as-synthesized MCM-41, presented bands characteristic of cetyltrimethylammonium bromide (CTAB) at around 962, 1472, 2859, and $2922 \mathrm{~cm}^{-1}$. The vibrational band at $962 \mathrm{~cm}^{-1}$ referred to the asymmetric stretching of the $\mathrm{CH}_{3}-\mathrm{N}^{+}$bond of the $\mathrm{CTA}^{+}$, coinciding with the previously reported stretching band of the $\mathrm{Si}-\mathrm{OH}$ bond. Those bands disappeared after calcination, and these findings suggested that the as-synthesized material was an organic-inorganic hybrid material and showed that the template surfactant had been removed. Several reports have shown that the FTIR spectra of the MCM-41 present these bands $[37,38]$.

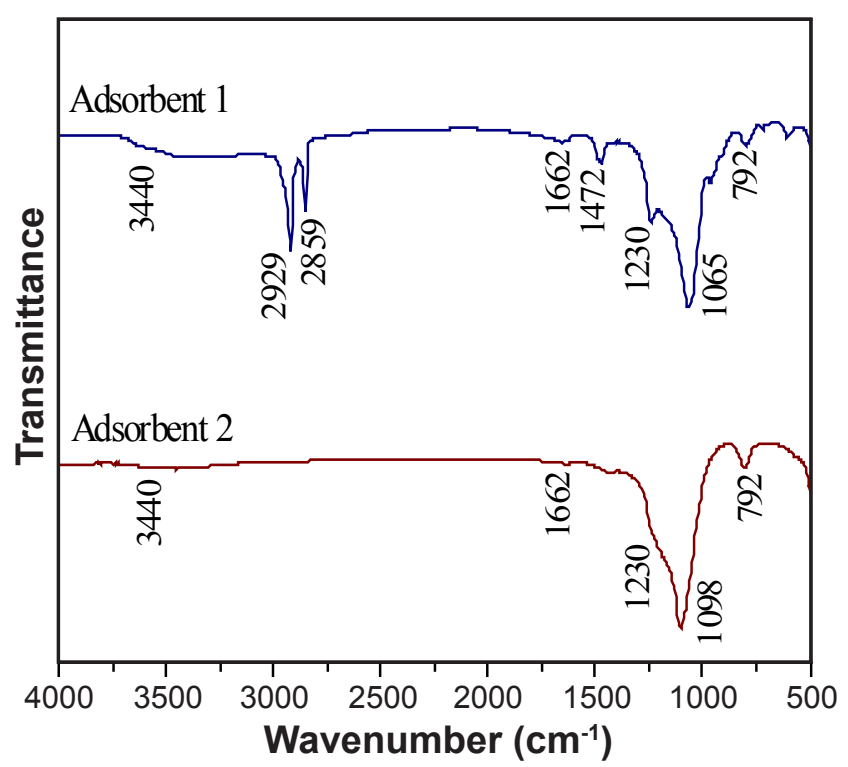

Figure 5: FTIR spectra of the synthesized mesoporous materials before and after calcination.

[Figura 5: Espectros de FTIR dos materiais porosos antes e após a calcinação.]

Dye adsorption: to test the adsorption performance of the mesoporous material made from an alternative silica source, the adsorption of BF-5G dye from an aqueous solution was performed. The $\mathrm{pH}$ chosen for the tests was lower than the isoelectric point $\mathrm{pH}_{\text {iep }}$ of MCM-41, which was equal to 4 . When the $\mathrm{pH}$ of the solution is lower than $\mathrm{pH}_{\text {iep }}$, a material surface is positively charged, and the sorption of anionic species to a positively charged sorbent occurs through the Coulomb force of attraction. The opposite occurs at higher $\mathrm{pH}$ values [25], when decreasing dye adsorption may be attributed to the competition of $\mathrm{OH}^{-}$with the dye ions for the adsorption sites on the material. The increasing number of hydroxyl groups decreases the number of positively charged sites and reduces the attraction between the dye and the adsorbent surface [24]. The positively charged surface facilitates the electrostatic interactions with the anionic dyes, which lead to a higher adsorption capacity [39]. As described in the literature [23], the complex structure of some dyes causes multiple possible interactions among dye molecules and adsorbents. Aromatic rings can interact with the alkyl radical of the surfactant through hydrophobic interactions, the azo group may interact with the silanol groups present on the surface of the mesoporous material through hydrogen bonds, and the sulfonic groups may also interact with the polar part of the surfactant through electrostatic interactions. The surfactant also promotes the formation of positive charges on the surface. Besides those interactions, the alkyl radical of the surfactant limits the accessible interfacial areas and also restricts diffusion of BF-5G into the materials, causing a structure collapse after the dye adsorption. In the case of the calcined sample, the surface is more stable (with silanol groups $\mathrm{SiOH}$ making those type of interactions with dye less efficient), since there is no alkyl radical from surfactant for making interactions with the dye.

Kinetic adsorption: the kinetic models of pseudo-first order and pseudo-second order were chosen to interpret the experimental data. The pseudo-first order model is represented by the equation rearranged to the linear form [40]:

$$
\log \left(q_{1}-q_{t}\right)=\log q_{m}-\frac{k_{1}}{2.303 m} \cdot t
$$

The pseudo-second order model can be expressed by:

$$
\frac{\mathrm{t}}{\mathrm{q}_{\mathrm{t}}}=\frac{\mathrm{t}}{\mathrm{k}_{2} \cdot \mathrm{q}_{2}^{2}}+\frac{\mathrm{t}}{\mathrm{q}_{2}} \cdot \mathrm{t}
$$

where $q_{1}, q_{2}$, and $q_{t}$ correspond to the amounts of dye adsorbed in equilibrium and, at any time $\mathrm{t}(\mathrm{min}), \mathrm{k}_{1}$ and $\mathrm{k}_{2}$, respectively, are the equilibrium rate constants of pseudofirst order adsorption $\left(\mathrm{min}^{-1}\right)$ and the pseudo-second order adsorption $\left(\mathrm{g}^{\mathrm{mg}} \mathrm{m}^{-1} \cdot \mathrm{min}^{-1}\right)$, and $\mathrm{q}_{\mathrm{m}}$ is the calculated adsorbed amount of dye in equilibrium $\left(\mathrm{mg} \cdot \mathrm{g}^{-1}\right)$. The experimental data, adjusted to the first- and second-order models, are presented in Figs. 6a and 6b, respectively. Fig. 6 shows that the adsorption of BF-5G dye reached equilibrium within a short span of time. This indicated that there was a strong affinity between the adsorbate surface and the dye molecule [23]. The rapid adsorption rate may be mainly attributed to the electrostatic interactions between the BF-5G and the MCM41 surface. It should be noted that positively-charged surfaces facilitate interactions with anionic groups [41]. 
BF-5G usually exists in a negative form, with the presence of groups such as $\mathrm{SO}_{3}^{-}, \mathrm{Cl}^{-}$, and $\mathrm{NH}_{2}^{-}$. Therefore, there is an electrostatic interaction with the positively charged MCM-41 surface.

The calculated kinetic parameters for the pseudo-first order and pseudo-second order models of BF-5G dye on mesoporous materials, with an initial concentration of $50 \mathrm{mg} . \mathrm{g}^{-1}$, are listed in Table III. As shown in Fig. 6,
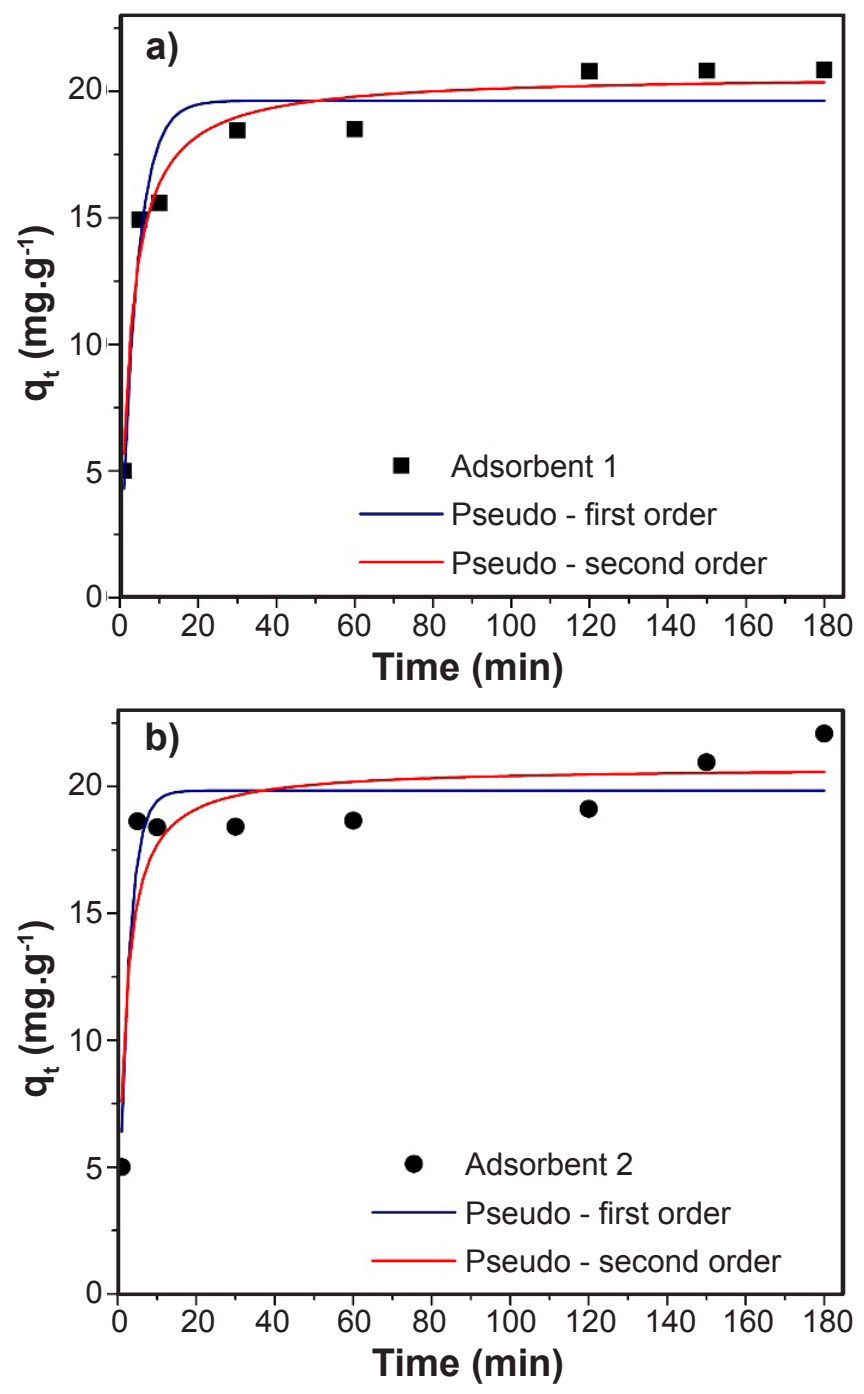

Figure 6: Adsorption kinetics of BF-5G dye onto mesoporous materials and non-linear fits: a) pseudo-first order; and b) pseudosecond order.

[Figura 6: Cinética de adsorção do corante BF-5G sobre materiais mesoporosos e ajustes não lineares: a) pseudoprimeira ordem; $e$ b) pseudossegunda ordem.] the pseudo-second order model fitted the experimental data better than pseudo-first order kinetic model for the Adsorbent 1 . The correlation coefficient $\mathrm{R}^{2}$ value for the pseudo-second order model (0.966) was greater than that of the pseudo-first order model for the Adsorbent 1. The opposite occurred for the Adsorbent 2. The adsorption process appeared to be controlled by chemical adsorption during the first $20 \mathrm{~min}$, which involved valence forces through electron sharing or exchange between adsorbent and adsorbate, as shown by Shao et al. [24], who reported on Mn/MCM-41 as an adsorbent for removing methyl blue from an aqueous solution.

Adsorption isotherms: the Freundlich and Langmuir models were chosen to analyze the experimental data. The empirical model developed by Freundlich describes heterogeneous systems of the adsorbent surface, given by:

$$
\mathrm{q}_{\mathrm{eq}}=\mathrm{K}_{\mathrm{F}} \cdot \mathrm{C}_{\mathrm{e}}{ }^{1 / n}
$$

The Langmuir adsorption model assumes that sorption takes place at specific homogeneous sites within the adsorbent [42]. Once a dye molecule occupies a site, no further adsorption can take place at that site. The mathematical expression that governs this model can be written as:

$$
q_{e q}=\frac{q_{m} \cdot K_{L} \cdot C_{e}}{1+K_{L} \cdot C_{e}}
$$

where $\mathrm{q}_{\mathrm{eq}}$ represents the amount of dye adsorbed at equilibrium $\left(\mathrm{mg} \cdot \mathrm{g}^{-1}\right), \mathrm{C}_{\mathrm{e}}$ is the equilibrium dye concentration $\left(\mathrm{mg} . \mathrm{L}^{-1}\right), \mathrm{q}_{\mathrm{m}}$ corresponds to the maximum adsorption capacity required to cover the monolayer $\left(\mathrm{mg} \cdot \mathrm{g}^{-1}\right), \quad \mathrm{K}_{\mathrm{F}}$ and $\mathrm{K}_{\mathrm{L}}$ represent, respectively, the Freundlich constant related to the adsorption capacity of the adsorbent $\left(\mathrm{L} \cdot \mathrm{mg}^{-1}\right)$ and the Langmuir constant related to the activation energy $\left(\mathrm{L}^{\mathrm{m}} \mathrm{mg}^{-1}\right), \mathrm{n}$ is the heterogeneity factor, and $1 / \mathrm{n}$ is related to the adsorption intensity. The adsorption equilibrium study provides information about the distribution of adsorbate on the surface of the adsorbent material and estimates its adsorption capacity. The non-linear models of Langmuir and Freundlich were fitted to the experimental equilibrium data, and the results are shown in Fig. 7. The data presented in Table IV indicate that the Freundlich model fitted the experimental data better, with a correlation coefficient higher than 0.97 for both samples. Compared to some others adsorbents,

Table III - Kinetic parameters of pseudo-first order and pseudo-second order models.

[Tabela III - Parâmetros cinéticos dos modelos de pseudoprimeira ordem e pseudossegunda ordem.]

\begin{tabular}{ccccccc}
\hline Sample & \multicolumn{3}{c}{ Pseudo-first order } & \multicolumn{3}{c}{ Pseudo-second order } \\
& $\mathrm{q}_{\max }\left(\mathrm{mg} \cdot \mathrm{g}^{-1}\right)$ & $\mathrm{k}_{1}\left(\mathrm{~min}^{-1}\right)$ & $\mathrm{R}^{2}$ & $\mathrm{q}_{\max }\left(\mathrm{mg} \cdot \mathrm{g}^{-1}\right)$ & $\mathrm{k}_{2}\left(\mathrm{~min}^{-1}\right)$ & 0.0183 \\
\hline Adsorbent 1 & 19.62 & 0.247 & 0.917 & 20.65 & 0.966 \\
Adsorbent 2 & 19.83 & 0.389 & 0.905 & 20.77 & 0.0277 & 0.847 \\
\hline
\end{tabular}


such as silica aerogel with a $\mathrm{q}_{\max }$ of $65.75 \mathrm{mg} / \mathrm{g}$ [11], and natural zeolite with a $\mathrm{q}_{\max }$ of $35.10 \mathrm{mg} / \mathrm{g}$ [43], both for methylene blue adsorption from aqueous solution, the values for maximum adsorption capacity for dyes obtained in this study were superior. The decrease in the maximum adsorption capacity for the calcined material is generally due to the loss of the van der Walls interactions present between the dye molecules and the walls of the mesopores.
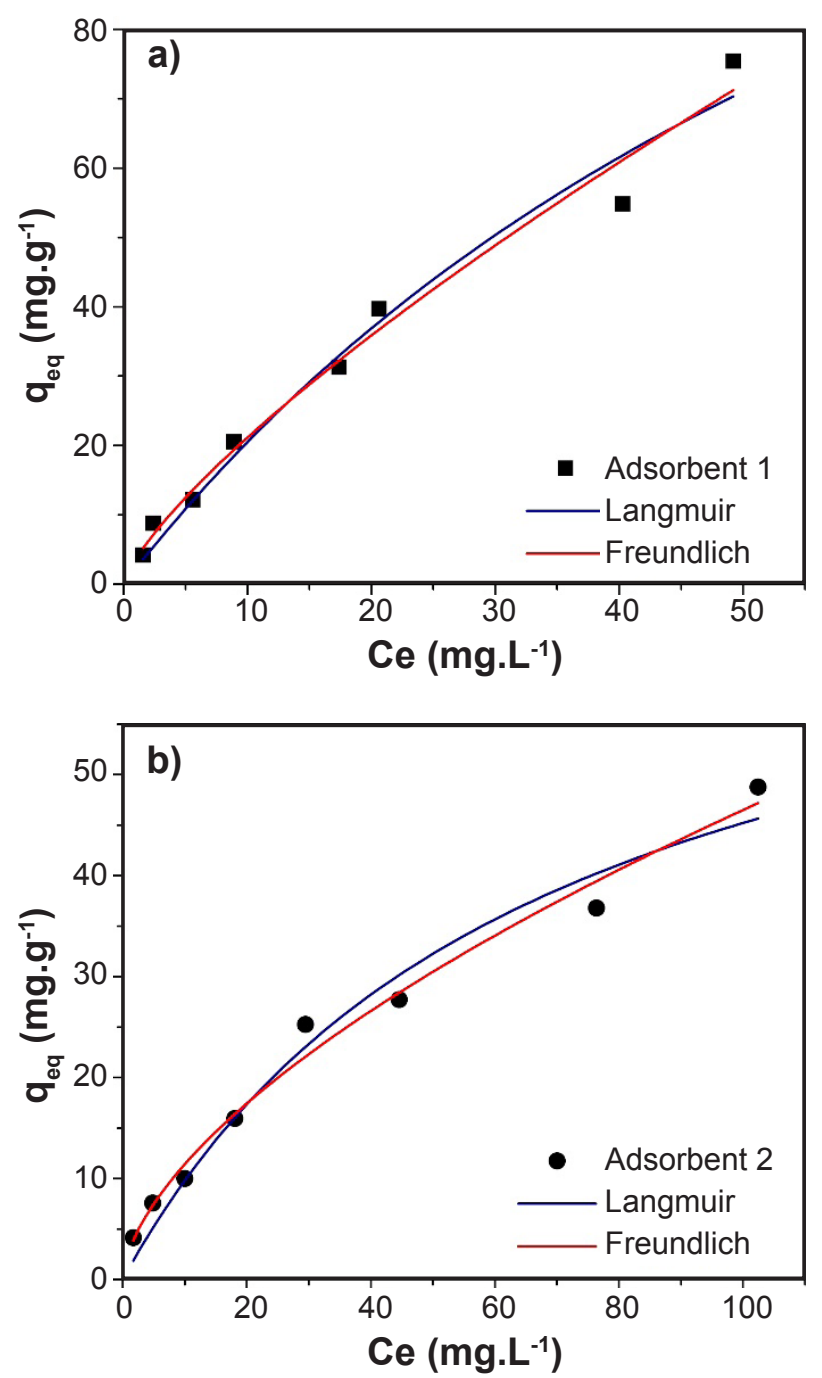

Figure 7: Adsorption isotherms of BF-5G onto mesoporous materials and non-linear adjustments: a) Langmuir; and b) Freundlich.

[Figura 7: Isotermas de adsorção do BF-5G sobre materiais mesoporosos e ajustes não lineares: a) Langmuir; e b) Freundlich.]

\section{CONCLUSIONS}

This study presents an economically attractive method for the synthesis of MCM-41 and its application on the adsorption of anionic dyes. It could be concluded from the results that clay can be used as an alternative silica source for the synthesis of MCM-41. The XRD and ED-XRF results showed that the acid leaching applied to the Chocolate clay increased the amount of $\mathrm{SiO}_{2}$ present in the material, eliminating other oxides. According to the XRD, ED-XRF, and FTIR results, the as-synthesized MCM-41 (Adsorbent 1) had an effective synthesis and produced a mesoporous material. On the other hand, in the case of the calcined sample (Adsorbent 2), XRD showed that its organization was reduced and became different from the MCM-41 material, possibly due to the calcination at $550{ }^{\circ} \mathrm{C}$. From the adsorption kinetics, it was possible to conclude there was a strong interaction between the surface of the adsorbate and the dye molecule, because of the rapid adsorption during the first minutes. The pseudo-second order model was a better fit to the experimental data for the Adsorbent 1, while the pseudo-first order model had a better fit for the Adsorbent 2. Based on the isotherm data, the Freundlich model fitted the experimental data better with a correlation coefficient above 0.97 for all samples. It was possible to confirm that the calcination decreased the maximum adsorption capacity of the sample, probably due to the loss of possible interactions between the surfactant, present in the pores of Adsorbent 1, and the different functional groups present in the BF-5G dye structure.

\section{ACKNOWLEDGMENTS}

The authors are grateful to financial support provided by Programa de Formação de Recursos Humanos (PRH25), Agência Nacional do Petróleo, Gás Natural e Biocombustíveis (ANP), PETROBRAS, Conselho Nacional de Desenvolvimento Científico e Tecnológico (CNPq) and Coordenação de Aperfeiçoamento de Pessoal de Nível Superior (CAPES).

\section{REFERENCES}

[1] N. Abidi, E. Errais, J. Duplay, A. Berez, A. Jrad, G. Schäfer, M. Ghazi, K. Semhi, M. Trabelsi-Ayadi, J. Clean. Prod. 86 (2015) 432.

[2] F. Harrelkas, A. Azizi, A. Yaacoubi, A. Benhammou, M.N. Pons, Desalination 235 (2009) 330.

Table IV - Isothermal parameters of non-linear adjustments of Langmuir and Freundlich.

[Tabela IV-Parâmetros isotérmicos de ajustes não lineares de Langmuir e Freundlich.]

\begin{tabular}{ccccccc}
\hline \multirow{2}{*}{ Sample } & \multicolumn{3}{c}{ Langmuir } & \multicolumn{3}{c}{ Freundlich } \\
& $\mathrm{q}_{\max }\left(\mathrm{mg} \cdot \mathrm{g}^{-1}\right)$ & $\mathrm{K}_{\mathrm{L}}\left(\mathrm{L} \cdot \mathrm{mg}^{-1}\right)$ & $\mathrm{R}^{2}$ & $\mathrm{~K}_{\mathrm{F}}\left(\mathrm{L} \cdot \mathrm{mg}^{-1}\right)$ & $\mathrm{n}$ & $\mathrm{R}^{2}$ \\
\hline Adsorbent 1 & 185.35 & 0.0124 & 0.973 & 3.659 & 1.312 & 0.980 \\
Adsorbent 2 & 75.57 & 0.0140 & 0.970 & 2.806 & 1.640 & 0.984 \\
\hline
\end{tabular}


[3] Y. Wang, Y. Xie, Y. Zhang, S. Tang, C. Guo, J. Wu, R. Lau, Chem. Eng. Res. Des. 114 (2016) 258.

[4] S.C.R. Santos, F.M. Oliveira, R.A.R. Boaventura, J. Clean. Prod. 126 (2016) 667.

[5] N. Rajamohan, M. Rajasimman, Eng. Technol. Appl. Sci. Res. 3 (2013) 387.

[6] S.C.R. Santos, R.A.R. Boaventura, J. Hazard. Mater. 291 (2015) 74.

[7] W. Deligeer, Y.W. Gao, S. Asuha, Appl. Surf. Sci. 257 (2011) 3524 .

[8] T.L. Silva, A. Ronix, O. Pezoti, L.S. Souza, P.K.T. Leandro, K.C. Bedin, K.K. Beltrame, A.L. Cazetta, V.C. Almeida, Chem. Eng. J. 303 (2016) 467.

[9] A. Rodríguez, J. García, G. Ovejero, M. Mestanza, J. Hazard. Mater. 172 (2009) 1311.

[10] M. Makrygianni, Z.G. Lada, A. Manousou, C.A. Aggelopoulos, V. Deimede, J. Environ. Chem. Eng. 7 (2019) 103163.

[11] H. Han, W. Wei, Z. Jiang, J. Lu, J. Zhu, J. Xie, Colloids Surf. A Physicochem. Eng. Asp. 509 (2016) 539.

[12] B. Yahyaei, S. Azizian, Chem. Eng. J. 209 (2012) 589.

[13] M.N. Chong, Z. Tneu, P.E. Poh, B. Jin, R. Aryal, J. Taiwan Inst. Chem. Eng. 50 (2015) 288.

[14] P.R. Souza, G.L. Dotto, N.P.G. Salau, J. Environ. Chem. Eng. 7 (2019) 102891.

[15] K. Ahmed, F. Rehman, C.T.G.V.M.T. Pires, A. Rahim, A.L. Santos, C. Airoldi, Microporous Mesoporous Mater. 236 (2016) 167.

[16] V. Meynen, P. Cool, E.F. Vansant, Microporous Mesoporous Mater. 125 (2009) 170.

[17] A.A. Azmi, M.A.A. Aziz, J. Environ. Chem. Eng. 7 (2019) 103022.

[18] V. Barbarossa, R. Viscardi, G. Maestri, R. Maggi, D. Mirabile Gattia, E. Paris, Mater. Res. Bull. 113 (2019) 64.

[19] C. Gérardin, J. Reboul, M. Bonne, B. Lebeau, Chem. Soc. Rev. 42 (2013) 4217.

[20] B.V. Sousa, M.G.F. Rodrigues, L.A. Cano, M.V. Cagnoli, J.F. Bengoa, S.G. Marchetti, G. Pecchi, Catal. Today 172 (2011) 152.

[21] Y. Kubota, Y. Nishizaki, H. Ikeya, M. Saeki, T. Hida, S. Kawazu, M. Yoshida, H. Fujii, Y. Sugi, Microporous Mesoporous Mater. 70 (2004) 135.

[22] A.C. Oliveira, L. Martins, D. Cardoso, Microporous Mesoporous Mater. 120 (2009) 206.
[23] B. Boukoussa, R. Hamacha, A. Morsli, A. Bengueddach, Arab. J. Chem. 10 (2013) S2160.

[24] Y. Shao, X. Wang, Y. Kang, Y. Shu, Q. Sun, L. Li, J. Colloid Interface Sci. 429 (2014) 25.

[25] L. Huang, Q. Huang, H. Xiao, M. Eic, Microporous Mesoporous Mater. 98 (2007) 330.

[26] M.G.F. Rodrigues, Cerâmica 49, 311 (2003) 146.

[27] J.S. Beck, J.C. Vartulli, W.J. Roth, M.E. Leonowicz, C.T. Kresge, K.D. Schmitt, C.T.-W. Chu, D.H. Olson, E.W. Sheppard, S.B. McCullen, J.B. Higgins, J.L. Schlenkert, J. Am. Chem. Soc. 114 (1992) 10834.

[28] A. Neaman, M. Pelletier, F. Villieras, Appl. Clay Sci. 22 (2003) 153.

[29] W.S. Lima, A.L.F. De Brito, M.G.F. Rodrigues, M.F. Mota, M.M. Silva, Mater. Sci. Forum 805 (2015) 662.

[30] P.N.M. Vasconcelos, W.S. Lima, M.L.P. Silva, A.L.F. Brito, H.M. Laborde, M.G.F. Rodrigues, Am. J. Anal. Chem. 4 (2013) 510.

[31] D. Woumfo, R. Kamga, F. Figueras, D. Njopwouo, Appl. Clay Sci. 37 (2007) 149.

[32] C.T. Kresge, M.E. Leonowicz, W.J. Eoth, J.C. Vartuli, J.S. Beck, Nature 359 (1992) 710.

[33] M. Bhagiyalakshmi, R. Anuradha, T.H. Jang, J. Porous Mater. 17 (2010) 475.

[34] A.J. Schwanke, D.M.A. Melo, A.O. Silva, S.B.C. Pergher, Cerâmica 59, 349 (2013) 181.

[35] D.P. Fabiano, B. Hamad, D. Cardoso, N. Essayem, J. Catal. 276 (2010) 190.

[36] D.M. Bezerra, I.W. Zapelini, K.N. Franke, M.E. Ribeiro, D. Cardoso, Mater. Charact. 154 (2019) 103.

[37] P. Sikarwar, U.K.A. Kumar, V. Gosu, V. Subbaramaiah, J. Environ. Chem. Eng. 6 (2018) 1736.

[38] V.L. Zholobenko, S.M. Holmes, C.S. Cundy, J. Dwyer, Microporous Mater. 11 (1997) 83.

[39] A. Benhamou, J.P. Basly, M. Baudu, Z. Derriche, R. Hamacha, J. Colloid Interface Sci. 404 (2013) 135.

[40] Y.S. Ho, G. Mckay, Chem. Eng. J. 70 (1998) 115.

[41] X. Xiao, F. Zhang, Z. Feng, S. Deng, Y. Wang, Physica E Low Dimens. Syst. Nanostruct. 65 (2015) 4.

[42] I. Langmuir, J. Am. Chem. Soc. 40 (1918) 1361.

[43] R. Han, J. Zhang, P. Han, Y. Wang, Z. Zhao, M. Tang, Chem. Eng. J. 145 (2009) 496.

(Rec. 23/09/2019, Rev. 08/01/2020, 09/03/2020, Ac. $17 / 03 / 2020)$ 